\title{
Active Modified Atmosphere Packaging of Fresh-cut Bell Peppers: Effect on Quality Indices
}

\author{
Helen Manolopoulou ${ }^{1}$, Gregory Lambrinos ${ }^{2} \&$ George Xanthopoulos $^{2}$ \\ ${ }^{1}$ Technological Educational Institute of Kalamata, Department of Crop Production, Antikalamos, Kalamata, \\ Greece \\ ${ }^{2}$ Agricultural University of Athens, Department of Natural Resources Management and Agricultural Engineering, \\ Athens, Greece \\ Correspondence: George Xanthopoulos, Agricultural University of Athens, Department of Natural Resources \\ Management and Agricultural Engineering, 75 Iera Odos Str. 118 55, Athens, Greece. Tel: 30-210-529-4031. \\ E-mail: xanthopoulos@aua.gr
}

Received: April 19, 2012 Accepted: May 15, 2012 Online Published: July 2, 2012

doi:10.5539/jfr.v1n3p148 URL: http://dx.doi.org/10.5539/jfr.v1n3p148

\begin{abstract}
Fresh-cut green bell peppers (Capsicum annuит L.) were stored in modified atmosphere packaging (MAP) made of impermeable high-density polyethylene film. Two in-packaging atmospheres and storage temperatures $\left(0{ }^{\circ} \mathrm{C}\right.$ and $5{ }^{\circ} \mathrm{C}$ ) were tested. The respiration rate of the unpackaged produce and the in-package gas concentration, mass loss, firmness, skin colour, ascorbic acid and visual quality of the packaged produce were estimated. Cutting, increased respiration rate of the unpackaged produce by $24 \%$ compared to the intact produce for the same storage temperature. After 5 days of storage at $5{ }^{\circ} \mathrm{C}$, significant $\mathrm{O}_{2}$ depletion of the active modified atmosphere was found. Limited mass loss ( $0.4-0.5 \%$ of the initial mass) and firmness degradation were estimated in both storage temperatures due to the beneficial effect of packaging. The hue angle $\left(\mathrm{h}^{*}\right)$ reduction was limited in all cases and the initial green colour was preserved. Initial ascorbic acid content was preserved at $0{ }^{\circ} \mathrm{C}$, but significantly increased at $5{ }^{\circ} \mathrm{C}$. The visual quality of the packaged produce was assessed by six trained panelists and found that was not significantly changed at $0{ }^{\circ} \mathrm{C}$ storage. In conclusion, the tested active MAP maintained the initial quality indices of fresh-cut peppers $\left(\mathrm{cv}\right.$. Twingo Fl) for up to 10 days at $0{ }^{\circ} \mathrm{C}$ but not at $5{ }^{\circ} \mathrm{C}$.
\end{abstract}

Keywords: capsicum annuum, active modified atmosphere packaging, quality indices, cut peppers

\section{Nomenclature:}

$\mathrm{a}^{*}$ : red/green balance

$\mathrm{b}^{*}$ : yellow/blue balance

$\mathrm{C}^{*}$ : chroma

df: degrees of freedom

$\mathrm{e}_{\mathrm{i}}$ : residuals of Eq. (1)

$\mathrm{h} *$ : hue

$\mathrm{L}^{*}$ : black/white balance

LSD: least significant difference

P1, P2, P3: gas mixtures $\left(\mathrm{O}_{2} / \mathrm{CO}_{2}: 5 \%: 10 \%, 5 \%: 15 \%, 21 \%: 0.03 \%\right)$

$\mathrm{R}_{\text {adj }}^{2}$ : coefficient of determination adjusted for the degrees of freedom

SEE: standard error of estimate

$\sigma^{2}$ : variance of the residuals $e_{i}$

\section{Introduction}

Minimally processed products are very popular with consumers since they are easy in use and healthy (Ohlsson, 1994). However, these products are highly perishable, deteriorate rapidly, and have short shelf-life. Therefore is important to extend their shelf-life with no compromise of their final quality (Huxsoll \& Bolin, 1989; Artés, Gómez, Aguayo, Escalona, \& Artés-Hernández, F., 2009; Beaulieu, 2011). Ahvenainen (2000) reported that the 
sensorial and nutritional shelf-life of the minimally processed products should be at least 4-7 days but generally longer storage times are needed for commercial use. Minimally processed products characterised by high respiration rates due to the wounds caused by the processing while biochemical changes are also observed. The establishment of a beneficial modified atmosphere is difficult to be achieved, since few packaging films are permeable enough to match the respiration rate of the fresh-cut products. Perforation-mediated packaging, are used to increase packaging permeability and reduce potential anaerobiosis (Ahevainainen, 2000).

Bell pepper has been adopted in various diets for their spicy taste and characteristic flavour and are significant source of vitamins A and C, antioxidants and carotenoid zeaxanthin. The latters are important in human diet and sensitive in minimal processing techniques (Raffo, Baimonte \& Paoletti, 2008). The recommended controlled atmospheres (CA) vary widely depended on the processed cultivars and the degree of processing. Information about the physiological behaviour of minimally processed bell peppers is limited and is mainly focused to passive modified atmosphere packaging (Conésa, Artés-Hernández, Geysen, Bart, \& Artés, 2007). Abe, Yoshimura, Zhou, Abe \& Iwata (1992) and Lopéz-Galvéz, El-Bassuoni, Nie \& Cantwell (1997) reported that minimally processed bell peppers stored at $0{ }^{\circ} \mathrm{C}$ retained their composition and visual quality for 6 to 15 days. Senesi, Prinzivalli, Sala \& Gennari (2000) argued with the adoption of low storage temperatures $\left(2{ }^{\circ} \mathrm{C}\right)$ since these can cause pitting due to sensitivity of peppers in chilling injuries. Senesi et al. (2000) suggested storage at $8{ }^{\circ} \mathrm{C}$, which retains satisfactorily the initial quality of the produce. Gorny (2001) suggested as pre-processing storage temperature of pepper, $7-10{ }^{\circ} \mathrm{C}$, and as post-processing, $0-5{ }^{\circ} \mathrm{C}$ adding that an atmosphere of $3 \% \mathrm{O}_{2}$ and $5-10 \% \mathrm{CO}_{2}$ can reduce the microbial growth and retain the visual quality of fresh-cut peppers.

In this paper was studied the physiological behaviour of fresh-cut green peppers ( $c$. Twingo Fl) packaged in impermeable high density polyethylene (HDPE) film, implementing two initial in-package $\mathrm{O}_{2} / \mathrm{CO}_{2}$ concentrations and two storage temperatures, $0{ }^{\circ} \mathrm{C}$ and $5{ }^{\circ} \mathrm{C}$, for 10 days. A new empirical model was developed to relate mass and firmness loss during the modified atmosphere packaging storage of fresh-cut green bell peppers.

\section{Materials and Methods}

\subsection{Raw Material}

Green bell peppers (Capsicum annuum L. cv. Twingo F1) were handpicked at their commercial maturity (firm and bright green) during June, July and August from a local farm in southern Greece. After harvest, peppers were immediately transported to the lab and sorted, removing those of poor quality (blemishes or defects) and non uniform. The sorted produce was disinfected with sodium hypochlorite $(100 \mathrm{ppm} \mathrm{NaOCl})$ in water at $5{ }^{\circ} \mathrm{C}$ for 2 min and rinsed with tap water at $5{ }^{\circ} \mathrm{C}$ for 2 min (Varoquaux \& Mazollier, 2002; Cantwell \& Suslow, 2002; Gonzaléz-Aguillar et al., 2004; Gil, Selma, López-Gálvez, \& Allende, 2009; Gil, Allende, \& Selma, 2011). Although in some European countries (Germany, the Netherlands, Switzerland and Belgium) the use of chlorine as disinfectant is not allowed (Oms-Oliu \& Soliva-Fortuny, 2011) in other European countries, chlorine is still in use as a 'processing aid' under the Directive 89/107/EEC (Gil et al., 2009). Finally, peduncle was removed from the disinfected peppers and the fruits chopped in uniform rings of $5 \mathrm{~mm}$ thickness. Equipment used in the processing, was sanitised before use with a chlorine solution. The pepper rings were sanitised again with chlorinated water at $5{ }^{\circ} \mathrm{C}$ for $2 \mathrm{~min}$ and rinsed with tap water at $5{ }^{\circ} \mathrm{C}$ for $2 \mathrm{~min}$. The remaining water on the pepper rings removed carefully with absorbing paper to prevent damaging the pepper rings. The adopted hygiene rules and low storage temperatures are consisted with the food safety regulations (Gonzaléz-Aguilar, Ayala-Zavala, Ruiz-Cruz, Acedo-Félix, \& Diaz-Cinco, 2004; Gil et al., 2011).

\subsection{Packaging and Storage Conditions}

Pepper rings of $100 \pm 2 \mathrm{~g}$ were placed in $20 \mu \mathrm{m}$ thick HDPE $\left(0.96 \mathrm{~g} \mathrm{~cm}^{-3}\right)$ packages, practically impermeable $\left(\mathrm{O}_{2}\right.$ permeability, $35.01 \mathrm{~mL} \mathrm{~m}^{-2} \mathrm{~d}^{-1}$ bar $^{-1}$ and $\mathrm{CO}_{2}$ permeability $50.58 \mathrm{~mL} \mathrm{~m} \mathrm{~d}^{-1}$ bar ${ }^{-1}, \mathrm{~S}^{-1} \mathrm{P}_{\mathrm{CO}_{2}} / \mathrm{P}_{\mathrm{O}_{2}}=1.4$ at $20{ }^{\circ} \mathrm{C}$, according to data provided by the film manufacturer) since gas flushing was applied. The overall packaging surface area was $1,200 \mathrm{~cm}^{2}$. The gas flushing was taken place in vacuum emptied packages, using a gas mixer (MAP Mix 9000, Denmark) and a vacuum compensation chamber (Multivac A. 300/16, Germany). Three initial in-package gas concentrations were tested: (i) $5 \% \mathrm{O}_{2}$ and $10 \% \mathrm{CO}_{2}$ balanced with $\mathrm{N}_{2}$ [P1], (ii) $5 \% \mathrm{O}_{2}$ and $15 \%$ $\mathrm{CO}_{2}$, balanced with $\mathrm{N}_{2}$ [P2], (iii) packaging film with one macro-perforation, $3 \mathrm{~mm}$ in diameter (the in-packaging atmosphere was near-ambient) [P3], (iv) control samples [C] placed on polystyrene trays $(120 \times 215 \times 15 \mathrm{~mm})$ and over wrapped with $13 \mu \mathrm{m}$ thick PVC film to minimise mass loss.

Gorny (2001) suggested for CA storage of fresh-cut bell peppers $\mathrm{O}_{2}$ and $\mathrm{CO}_{2}$ of $3 \%$ and $5-10 \%$ respectively, noting that injuries due to increased $\mathrm{CO}_{2}$ levels vary significantly among cultivars. Lopéz-Galvéz et al. (1997) reported that storage conditions, $5{ }^{\circ} \mathrm{C}$ and $10 \% \mathrm{CO}_{2}$ can retain product quality and delay decay. Based on the previous suggestions was decided to test two different initial atmospheres, one of which with $\mathrm{CO}_{2}>10 \%$, to 
examine the physiological behaviour of the specific pepper variety and compare it with the respective under ambient conditions. All the tested packages were stored at $0{ }^{\circ} \mathrm{C}$ and $5{ }^{\circ} \mathrm{C}$, and $90 \%$ relative humidity in darkness for 10 days as Kang \& Lee (1997) suggested. Six packages were prepared per sampling date, treatment (P1, P2, $\mathrm{P} 3$ and $\mathrm{C})$ and storage temperature $\left(0{ }^{\circ} \mathrm{C}\right.$ and $\left.5{ }^{\circ} \mathrm{C}\right)$. For gas analysis and mass loss estimation, ten bags per treatment and storage temperature were prepared. Every experiment conducted in triplicate.

\subsection{Gas Analysis of the In-package Atmosphere}

The in-package atmosphere $\left(\mathrm{O}_{2}\right.$ and $\left.\mathrm{CO}_{2}\right)$ was daily measured with a headspace gas analyser (CheckMate 9000 , PBI Dansensor Co., Denmark), drawing up $2 \mathrm{~mL}$ of air samples. Sampling took place with a hypodermic needle through a septum pasted on the packaging. Ten bags per treatment (P1, P2, P3) and storage temperature were prepared for gas analysis.

\subsection{Respiration Rate (RR) of Whole and Fresh-cut Peppers}

The $\mathrm{CO}_{2}$ production rate of whole and fresh-cut unpackaged peppers was measured with a closed respiratory cell system having 3.9-6.3\% uncertainty in measurements (Mitropoulos, Lamprinos, \& Manolopoulou, 2000). 110 \pm 5 $\mathrm{g}$ of unpackaged whole peppers and $100 \pm 2 \mathrm{~g}$ fresh-cut peppers were placed in $962 \mathrm{~mL}$ gas tight containers under atmospheric conditions $\left(20.95 \% \mathrm{O}_{2}, 0.038 \% \mathrm{CO}_{2}, 79.012 \% \mathrm{~N}_{2}\right)$ and left for the rest of the measuring period. Six gas samples per storage temperature $\left(0{ }^{\circ} \mathrm{C}\right.$ and $\left.5{ }^{\circ} \mathrm{C}\right)$ were daily taken from the headspace and used for estimation of the respiration rate.

\subsection{Mass Loss}

Mass loss was calculated as (\%) of the initial mass, with an electronic scale of $\pm 0.01 \mathrm{~g}$ accuracy. Weighting carried out in controlled air conditions to avoid moisture condensation on the packages. In the packages used for mass loss estimation, was not detected visible water drips from the packaged pepper rings. The mass loss of the 10 packages per treatment $(\mathrm{P} 1, \mathrm{P} 2, \mathrm{P} 3$, and $\mathrm{C})$ and storage temperature was estimated at the beginning of the experiment and on the $3^{\text {rd }}, 6^{\text {th }}, 8^{\text {th }}$ and $10^{\text {th }}$ day of the experiment.

\subsection{Firmness}

Firmness was measured with a Texture Analyser TA-XT2i (SMS, England) using a Kramer shear cell, containing $10 \mathrm{~g}$ of sample. The speed of the probe was set to $1 \mathrm{~mm} \mathrm{~s}^{-1}$. Firmness was evaluated at the maximum rupture force $(\mathrm{N})$, defined from a typical force-distance diagram. Measurements of the firmness were carried out at the beginning of the experiment and on the $3^{\text {rd }}, 6^{\text {th }}$ and $10^{\text {th }}$ day in 6 packages per treatment $(\mathrm{P} 1, \mathrm{P} 2, \mathrm{P} 3$, and $\mathrm{C})$ and storage temperature.

\subsection{Colour Measurement}

Colour was measured on the CIE L*a*b* chromatic space with a Minolta CR-300 Chromameter (Minolta Corp., Japan). The instrument was initially calibrated using a white ceramic tile ( $Y=92.6 \mathrm{X}=0.313 \mathrm{y}=0.319)$. The $\mathrm{L}^{*}$ chromatic variable, ranges from 0 (black) to 100 (white) and is an indicator of the lightening or darkening due to the physicochemical changes taking place during storage. The $a^{*}$ measures the degree of redness $\left(+a^{*}\right)$ and greenness $\left(-a^{*}\right)$ while the $b^{*}$ the degree of yellowness $\left(+b^{*}\right)$ and blueness $\left(-b^{*}\right)$. The measured $a^{*}$ and $b^{*}$ values were used to estimate chroma values, $\mathrm{C}^{*}=\left(\mathrm{a}^{* 2}+\mathrm{b}^{* 2}\right)^{0.5}$ and hue angle degrees $\mathrm{h}^{*}=\arctan ^{-1}\left(\mathrm{~b}^{*} / \mathrm{a}^{*}\right)$. In fact, hue angle values greater than $90^{\circ}$ correspond to intense green colour while values close to $90^{\circ}$ to yellow. Chroma defines the colour intensity or purity of the hue. Values close to 0 correspond to neutral colours and values close to 60 to bright colours (McGuire 1992). Depending on the sampling scheme and accuracy, the $\mathrm{L}^{*}, \mathrm{a}^{*}, \mathrm{~b}^{*}, \mathrm{~h}^{*}$ or $\mathrm{C}^{*}$ values can provide a satisfactory colour description (Manolopoulou, Xanthopoulos, Douros \& Lambrinos, $2010)$. Colour was evaluated at the beginning and on the $3^{\text {rd }}, 6^{\text {th }}$ and $10^{\text {th }}$ day, in 6 packages per treatment $(\mathrm{P} 1, \mathrm{P} 2$, $\mathrm{P} 3$, and $\mathrm{C}$ ) and storage temperatures.

\subsection{Ascorbic Acid}

Ascorbic acid was determined using the 2,6 dichlorophenolindophenol method (AOAC 1990) and expressed in $\mathrm{mg}$ per $100 \mathrm{~g}$ of the initial fruit mass. Measurements were taken at the beginning and at the end of the storage $\left(10^{\text {th }}\right.$ day). Measurements of the ascorbic acid were carried out in 6 packages per treatment $(\mathrm{P} 1, \mathrm{P} 2, \mathrm{P} 3$, and $\mathrm{C})$ and storage temperature.

\subsection{Quality Evaluation}

The visual quality of the packaged produce was assessed by a panel of six trained judges adopting a hedonistic scale from 1 to 9 , rating with $9=$ excellent, no visual defects, $7=$ good minor defects, $5=$ =fair moderated defects, $3=$ poor moderately severe defects, $1=$ unusable. In this study, score of 6 was considered as the marketable limit for a fresh-cut produce (López-Gálvez et al., 1997). The assessment was carried out at the beginning of the experiment and on the $3^{\text {rd }}, 6^{\text {th }}$ and $10^{\text {th }}$ day, in 6 packages per treatment $(\mathrm{P} 1, \mathrm{P} 2, \mathrm{P} 3$, and C) and storage 
temperature.

\subsection{Experimental Design and Statistical Analysis}

The experiment followed a full factorial design (storage temperaturextreatment $\times$ storage time) and subjected to the analysis of variance (ANOVA) using Statgraphics Plus 5.1 (Statpoint Technologies, Inc, USA). Mean values were subjected to Fisher's Least Significant Difference test (LSD) at confidence level $p \leq 0.05$. The adopted test is liberal with respect to the comparison wise error rate, but is powerful for detecting true differences among means (Gacula \& Sign 1984). In the figures and tables are presented the mean values from three experimental series, since no significant differences were found among the three experimental series $(p \leq 0.05)$.

\section{Results and Discussion}

\subsection{Respiration Rate}

Respiration rate (RR) of the unpackaged fresh-cut and whole peppers was not significantly different at $0{ }^{\circ} \mathrm{C}$ but was significantly different at $5{ }^{\circ} \mathrm{C}$ (cf. Figure 1). At $5{ }^{\circ} \mathrm{C}$ the RR of the fresh-cut pepper increased from $0.62 \mathrm{~mL}$ $\mathrm{CO}_{2} \mathrm{~h}^{-1} 100 \mathrm{~g}^{-1}\left(1^{\text {st }}\right.$ day) up to $0.98 \mathrm{~mL} \mathrm{CO}_{2} \mathrm{~h}^{-1} 100 \mathrm{~g}^{-1}$ ( $9^{\text {th }}$ day) and then sharply decreased at $0.47 \mathrm{~mL} \mathrm{CO}_{2} \mathrm{~h}^{-1}$ $100 \mathrm{~g}^{-1}\left(10^{\text {th }}\right.$ day) probably due to the exhaustion of the necessary substrates for retaining high RR. The RR of the whole peppers at $5{ }^{\circ} \mathrm{C}$ reduced from $0.5 \mathrm{~mL} \mathrm{CO}_{2} \mathrm{~h}^{-1} 100 \mathrm{~g}^{-1}$ (1 $1^{\text {st }}$ day) to $0.27 \mathrm{~mL} \mathrm{CO}_{2} \mathrm{~h}^{-1} 100 \mathrm{~g}^{-1}$ and remained constant at this level for the last three days of the storage. At $5{ }^{\circ} \mathrm{C}$, the initial RR of the fresh-cut peppers was $23.5 \%$ higher than the RR of whole produce. The measured RR values were similar to those reported by Kang \& Lee (1997) who observed an increase of 38\% in RR of fresh-cut peppers during a six-day storage at $5{ }^{\circ} \mathrm{C}$. The mean RR values for the fresh-cut pepper at $0{ }^{\circ} \mathrm{C}$ was $0.27 \pm 0.13 \mathrm{~mL} \mathrm{CO}_{2} \mathrm{~h}^{-1} 100 \mathrm{~g}^{-1}$ and at $5{ }^{\circ} \mathrm{C}$ was $0.69 \pm 0.17 \mathrm{~mL} \mathrm{CO}_{2} \mathrm{~h}^{-1} 100 \mathrm{~g}^{-1}$. At $0{ }^{\circ} \mathrm{C}$ the difference of the mean RR values between whole and fresh-cut produce was $<1 \%$ whereas at $5{ }^{\circ} \mathrm{C}$ was $47 \%$. The statistical analysis highlighted that temperature control is important in reducing the injury induced metabolic activity in whole and fresh-cut produce although ANOVA pointed out that the interaction of storage time and treatments was also significant in both storage temperatures.
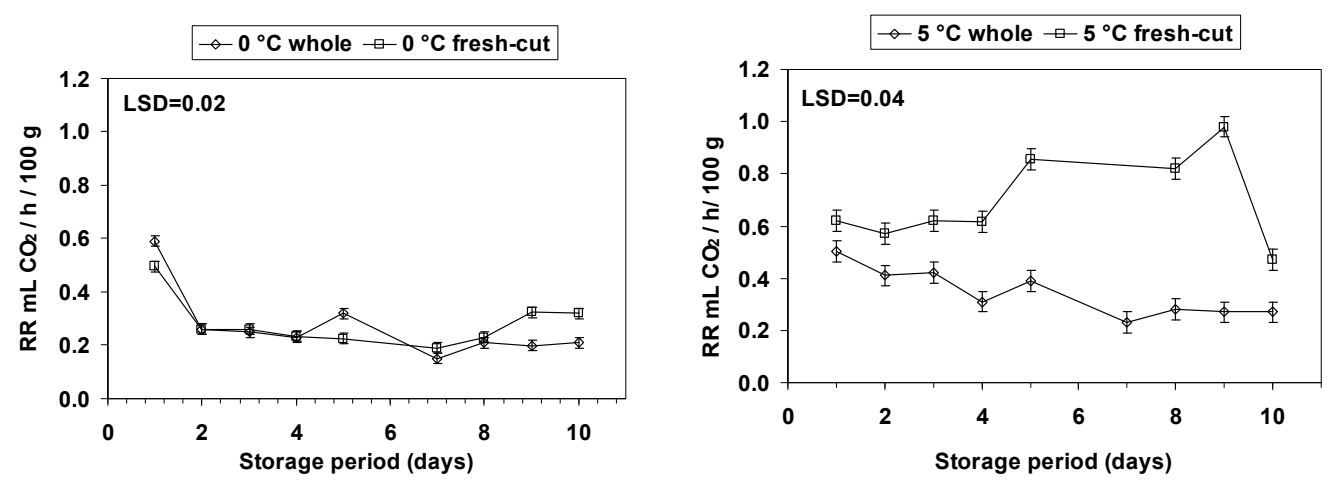

Figure 1. Respiration rates of unpackaged fresh-cut and whole peppers stored at 0 and $5{ }^{\circ} \mathrm{C}$. Data points are means of 18 replicates \pm LSD

\subsection{Gas Composition}

Evolution of $\mathrm{O}_{2}$ and $\mathrm{CO}_{2}$ during the storage of fresh-cut peppers at $0{ }^{\circ} \mathrm{C}$ and $5{ }^{\circ} \mathrm{C}$ is showed in Figure 2 . As it was expected, the $\mathrm{CO}_{2}$ accumulation in the fresh-cut produce packaging was rapid at $5{ }^{\circ} \mathrm{C}$. The ANOVA showed that $\mathrm{O}_{2}$ and $\mathrm{CO}_{2}$ evolution was storage temperature, storage time and treatment dependent. Significant difference noted in the $\mathrm{CO}_{2}$ levels among the P1, P2 and P3 treatments. Similar $\mathrm{O}_{2} / \mathrm{CO}_{2}$ evolution observed for P1 and P2 treatments at both tested temperatures. At $0{ }^{\circ} \mathrm{C}$, the $\mathrm{O}_{2}$ decreased from the initial $5 \%$ to the final $0.5 \%$ and $0.2 \%$ for $\mathrm{P} 1$ and $\mathrm{P} 2$ respectively, whereas in $\mathrm{P} 3$ the $\mathrm{O}_{2}$ concentration stayed above $19 \%$. At $5{ }^{\circ} \mathrm{C}$, the respiratory activity consumed $\mathrm{O}_{2}$ up to the $5^{\text {th }}$ day of storage although at the end of the storage no tissue injuries or off flavours were detected. Further investigation is needed on the effect of the headspace at low $\mathrm{O}_{2}$ or high $\mathrm{CO}_{2}$ concentrations, as well as the tolerance of the packaged peppers at the formed $\mathrm{O}_{2} / \mathrm{CO}_{2}$ in-package atmospheres. The $\mathrm{O}_{2}$ levels between $\mathrm{P} 1$ and $\mathrm{P} 2$ for the two tested temperatures were not significant different. At $0{ }^{\circ} \mathrm{C}$, the $\mathrm{CO}_{2}$ concentration increased by $28 \%$, from $10 \%$ to $12.8 \%$ at $\mathrm{P} 1$, by $8 \%$, from $15 \%$ to $16.2 \%$ at $\mathrm{P} 2$ and at $\mathrm{P} 3$ increased up to $2.28 \%$. At $5{ }^{\circ} \mathrm{C}$, the $\mathrm{CO}_{2}$ increased up to $6.03 \%$ at $\mathrm{P} 3$ while at $\mathrm{P} 1$ and $\mathrm{P} 2$ increased by $58 \%$, from $10 \%$ to 
$15.8 \%$ and by $31 \%$, from $15 \%$ to $19.6 \%$ respectively.
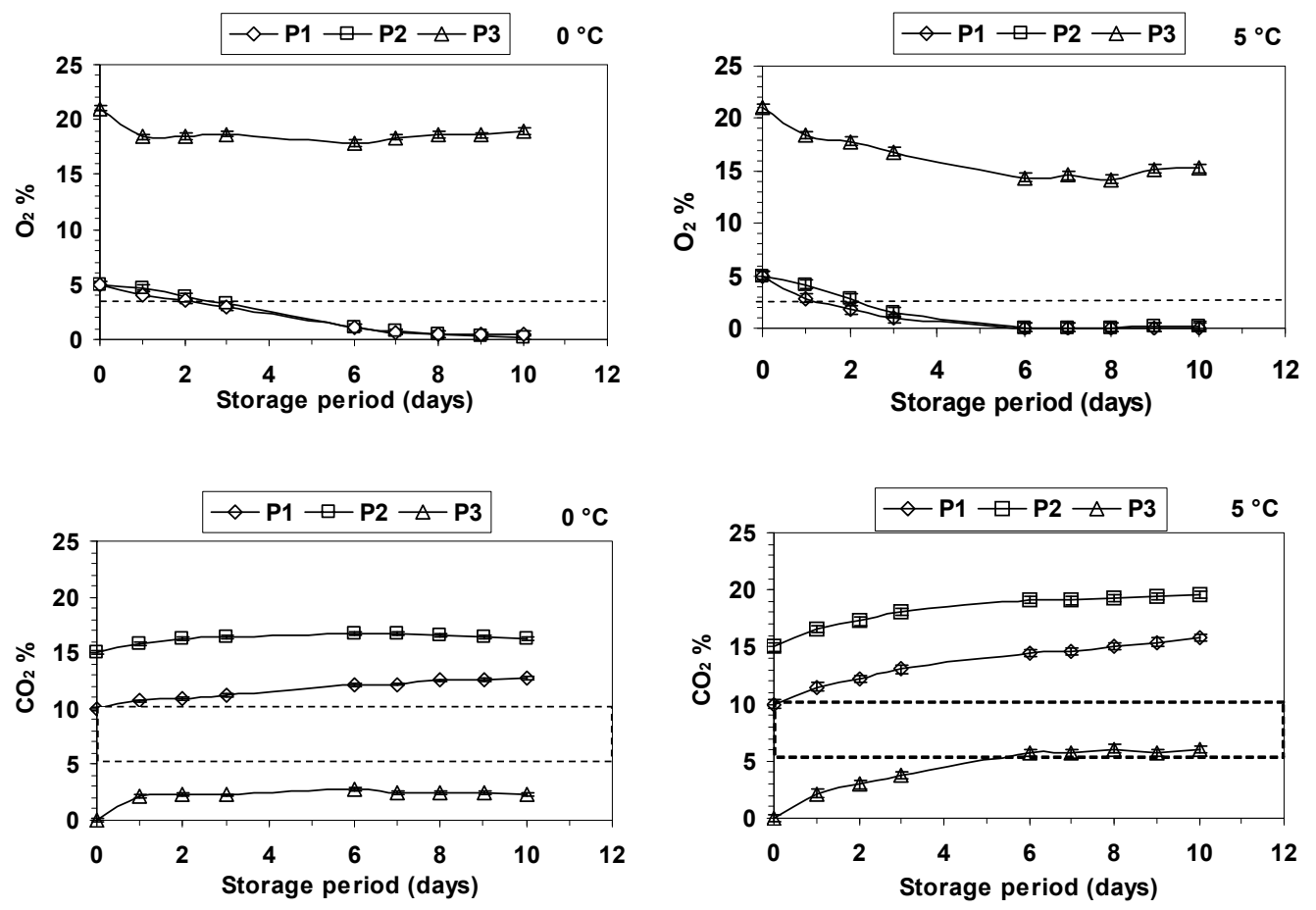

Figure 2. Changes in $\mathrm{O}_{2}$ and $\mathrm{CO}_{2}$ of packaged fresh-cut peppers stored at 0 and $5{ }^{\circ} \mathrm{C} . \mathrm{P} 1, \mathrm{P} 2, \mathrm{P} 3$ are $\mathrm{O}_{2}: \mathrm{CO}_{2}$ mixtures respectively, 5\%:10\%, 5\%:15\%, 21\%:0.03\%. Data points are means of 30 replicates \pm LSD; $\left[0{ }^{\circ} \mathrm{C}\right.$ :

$\left.\mathrm{LSD}_{\mathrm{O}_{2}}=0.25 ; \mathrm{LSD}_{\mathrm{CO}_{2}}=0.14 ; 5^{\circ} \mathrm{C}: \mathrm{LSD}_{\mathrm{O}_{2}}=0.40 ; \mathrm{LSD}_{\mathrm{CO}_{2}}=0.33\right]$. Horizontal dotted lines demarcate the suggested $\mathrm{O}_{2}$ to $\mathrm{CO}_{2}$ levels for fresh-cut green bell peppers

\subsection{Mass Loss}

Packaging reduced mass loss of Twingo F1 whole peppers (Manolopoulou et al., 2010). Similarly, the packaging film, used in P1, P2 and P3 reduced significantly mass loss of the fresh-cut produce (cf. Figure 3) with no visible formation of water drips in the packages. At the end of the storage $\left(10^{\text {th }}\right.$ day) at $0{ }^{\circ} \mathrm{C}$ and $5{ }^{\circ} \mathrm{C}$, packaged produce lost $<0.5 \%$ of its initial weight, whereas control samples lost $1.4 \%$ and $2.6 \%$ respectively which lies below the acceptable limit of 5\% (Manolopoulou et al., 2010). The ANOVA showed that the interaction of the storage temperature, storage time and treatment, affected significantly mass loss $(p \leq 0.001)$.
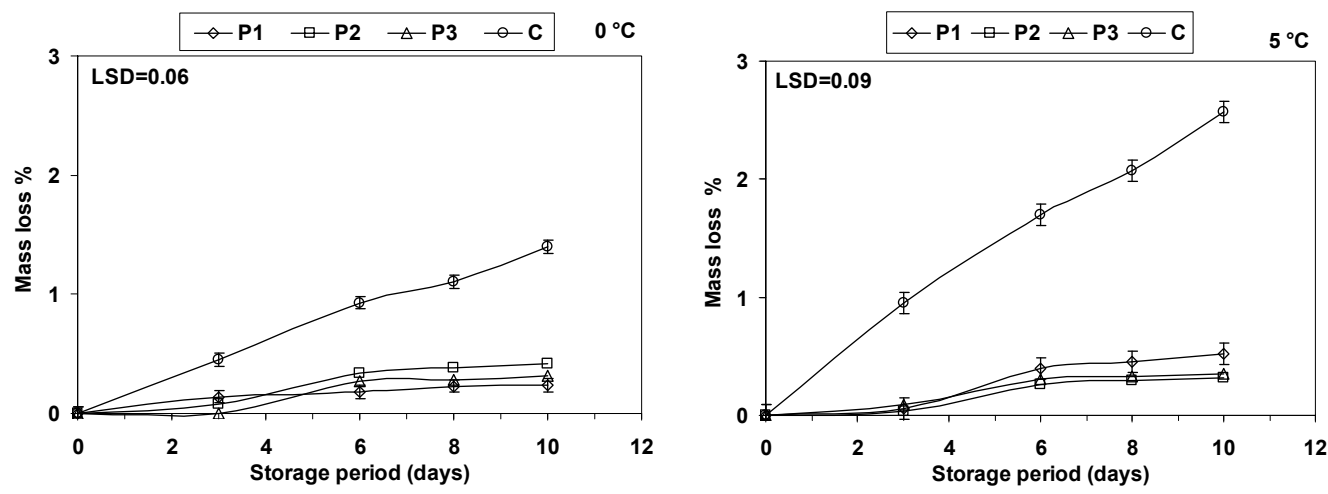

Figure 3. Mass loss of the packaged fresh-cut peppers stored at 0 and $5{ }^{\circ} \mathrm{C}$. P1, P2, P3 are $\mathrm{O}_{2}: \mathrm{CO}_{2}$ mixtures respectively, 5\%:10\%, 5\%:15\%, 21\%:0.03\%. C denotes control samples. Data points are the means of 30 replicates $\pm \mathrm{LSD}$ 


\subsection{Firmness}

The ANOVA showed that only the interaction of treatment with storage time affected significantly firmness $\left(p=0.0087<0.05\right.$ ). At $0{ }^{\circ} \mathrm{C}$, the firmness of the fresh-cut produce, (cf. Table 1 ) increased by $5-18 \%$ at the end of the storage $\left(10^{\text {th }}\right.$ day), which was significant only for P1 and P2. At $5{ }^{\circ} \mathrm{C}$, firmness increased at the end of the storage by $3-11 \%$, which was significant only for P1. The employed firmness test is catastrophic and introduces an experimental error due to inevitable variability among the tested samples, which should be considered in the statistical inference.

Table 1. Effect of storage temperature, treatment and storage time on the mean rupture force $(\mathrm{N})$ of packaged fresh-cut green bell peppers stored at 0 and $5{ }^{\circ} \mathrm{C}$

\begin{tabular}{|c|c|c|c|c|c|c|}
\hline Storage & Storage & P1 & $\mathrm{P} 2$ & P3 & $\mathrm{C}$ & F ANOVA \\
\hline days & Temperature & & & & & \\
\hline 0 & $0{ }^{\circ} \mathrm{C}$ & $337.4 \pm 12.8 \mathrm{~A}$ & $337.4 \pm 12.8 \mathrm{~A}$ & $337.4 \pm 12.8 \mathrm{~A}$ & $337.4 \pm 12.8 \mathrm{~A}$ & \\
\hline 3 & & $389.9 \pm 10.5 \mathrm{aBC}$ & $349.5 \pm 16.7 \mathrm{bAB}$ & $386.2 \pm 16.9 \mathrm{abC}$ & $357.9 \pm 10.7 \mathrm{abAB}$ & $2.31^{*}$ \\
\hline 6 & & $351.7 \pm 11.9 \mathrm{aAB}$ & $347.6 \pm 13.4 \mathrm{aAB}$ & $383.2 \pm 17.8 \mathrm{aBC}$ & $370.2 \pm 16.7 \mathrm{aAB}$ & $0.91^{N S}$ \\
\hline 10 & & $399.8 \pm 11.7 \mathrm{aC}$ & $377.0 \pm 11.8 \mathrm{abB}$ & $339.5 \pm 14.5 \mathrm{bAB}$ & $355.8 \pm 12.9 \mathrm{bAB}$ & $2.92 *$ \\
\hline F ANOVA & & $5.52^{*}$ & $2.01^{N S}$ & $4.07 *$ & $1.61^{N S}$ & \\
\hline 0 & $5^{\circ} \mathrm{C}$ & $337.4 \pm 12.8 \mathrm{~A}$ & $337.4 \pm 12.8 \mathrm{~A}$ & $337.4 \pm 12.8 \mathrm{~A}$ & $337.4 \pm 12.8 \mathrm{~A}$ & \\
\hline 3 & & $371.2 \pm 15.0 \mathrm{abBC}$ & $349.0 \pm 11.7 \mathrm{aA}$ & $386.9 \pm 13.5 \mathrm{bB}$ & $369.9 \pm 18.0 \mathrm{abB}$ & $1.43^{*}$ \\
\hline 6 & & $407.0 \pm 15.2 \mathrm{cC}$ & $327.3 \pm 15.8 \mathrm{aA}$ & $356.0 \pm 16.9 \mathrm{abAB}$ & $376.9 \pm 18.7 \mathrm{bcB}$ & $9.35^{*}$ \\
\hline 10 & & $373.7 \pm 15.2 \mathrm{aBC}$ & $356.3 \pm 16.5 \mathrm{aA}$ & $348.5 \pm 18.7 \mathrm{aAB}$ & $373.4 \pm 16.2 \mathrm{aB}$ & $0.68^{N S}$ \\
\hline F ANOVA & & $7.42^{*}$ & $0.94^{N S}$ & $2.85 *$ & $3.49^{*}$ & \\
\hline
\end{tabular}

Values followed by different lowercase letters in the same row, show significant difference among treatments, $\mathrm{p} \leq 0.05$; Values followed by different uppercase letters in the same column, show significant difference among storage days, $\mathrm{p} \leq 0.05$; Values denote means \pm std; $N S=$ not significant; ${ }^{*}=$ significant at $\mathrm{p} \leq 0.05$.

Nunes \& Emond (2003) discussed that increase of firmness is water loss induced and results in toughening of the epidermis in fleshy tissues, fact which was visible in control samples and less visible in P1, P2 and P3 treatments (cf. Figure $4 \mathrm{a}$ ) where mass loss was limited $(<0.3 \%)$ for both storage temperatures. Smith, Waldron, Maness \& Perkins-Veazie (2003) reported that mass loss and firmness are related. Therefore, regression analysis of mass loss with respect to treatment and firmness, resulted in Eq. (1), where $\mathrm{R}_{\text {adj }}^{2}=0.633$ and $\mathrm{SEE}=0.279$. Therefore, if firmness is known, then mass loss can be evaluated without prior knowledge of the initial weight.

$$
\begin{aligned}
\text { Mass loss }(\%)= & 0.076+4.656 \times 10^{-4} \times \text { irmness } \times \text { P } 1-1.463 \times 10^{-4} \times \text { firmness } \times P 2 \\
& -2.189 \times 10^{-4} \times \text { firmness } \times P 3+23.395 \times 10^{-4} \times \text { firmness } \times C
\end{aligned}
$$

The P1, P2 and P3 terms are indicator variables taking the value 1 if true and 0 if false. Therefore Eq. (1) yielded four separate lines (cf. Figure 4a), one for each treatment. For P1 treatment, the model becomes:

$$
\text { Mass loss }(\%)=0.076+4.656 \times 10^{-4} \times \text { firmness }
$$

and for $\mathrm{P} 2$ treatment:

$$
\text { Mass loss }(\%)=0.076-1.463 \times 10^{-4} \times \text { firmness }
$$

Further statistical analysis of Eq. 1 showed that statistically significant relationship exists between the correlated variables and statistical significant difference exists among the slopes for C, P1, P2 and P3 $(p \leq 0.05)$. Finally, the efficiency of the model (cf. Eq. 1) was further tested, plotting the residual error graph (cf. Figure 4b) to examine the homoscedasticity hypothesis. From this plot (cf. Figure $4 \mathrm{~b}$ ) was found that the homoscedasticity hypothesis is fulfilled since the plotted studentised residuals of the predicted mass loss (\%) show no systematic patterns and are allocated around zero in a value zone between 3.0 and -3.0. 

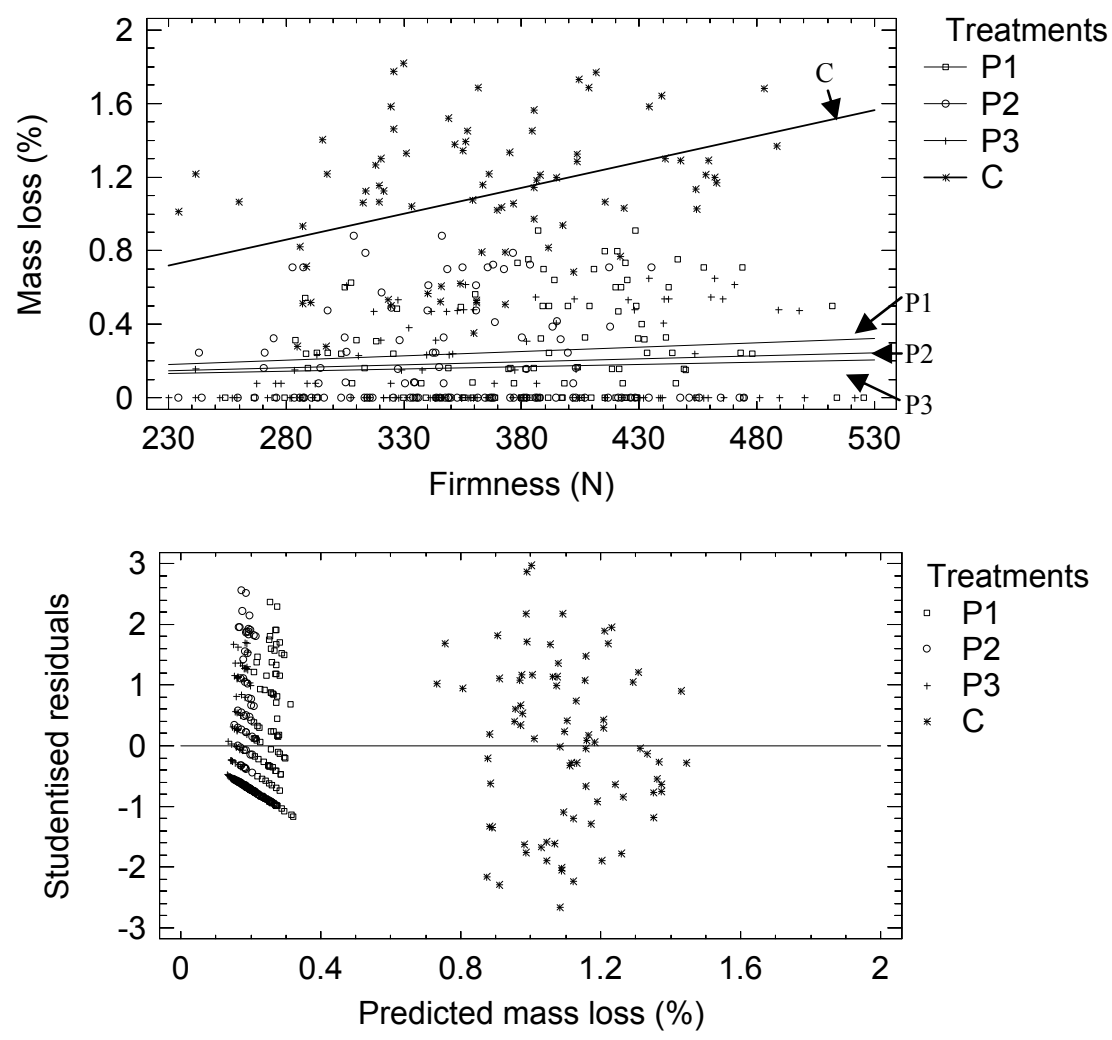

(a)

(b)

Figure 4. (a) Mass loss (\%) change with firmness (N) of fresh-cut packaged peppers for P1, P2, P3 and C; (b) Residual error plot of the predicted mass loss (\%). P1, P2, $\mathrm{P} 3$ are $\mathrm{O}_{2}: \mathrm{CO}_{2}$ mixtures respectively, $5 \%: 10 \%$, 5\%:15\%, 21\%:0.03\%. C denotes control samples

\subsection{Colour Evaluation}

The ANOVA of treatment, storage temperature and, storage time and the way these parameters affect colour parameters $\left(\mathrm{L}^{*}, \mathrm{C}^{*}\right.$ and $\left.\mathrm{h}^{*}\right)$ are tabulated in Tables 2 and 3 . The lightness $\left(\mathrm{L}^{*}\right)$ of the fresh-cut produce on the initial day was $32.5 \pm 3.4$. At the end of the storage $\left(10^{\text {th }}\right.$ day $)$, the $\mathrm{L}^{*}$ values at $0{ }^{\circ} \mathrm{C}$, were significantly reduced at $\mathrm{P} 1$ and $\mathrm{P} 2$ and were significantly different from the $\mathrm{L}^{*}$ values at P3. Only P2 had significantly different $\mathrm{L}^{*}$ values from the control $\mathrm{L}^{*}$ values. At $5{ }^{\circ} \mathrm{C}$, the $\mathrm{L}^{*}$ values were significantly reduced at $\mathrm{P} 1$ and did not changed significantly at $\mathrm{P} 2, \mathrm{P} 3$ and $\mathrm{C}$. The initial chroma $\left(\mathrm{C}^{*}\right)$ value was $25.8 \pm 2.6$. At $0{ }^{\circ} \mathrm{C}$, the $\mathrm{C}^{*}$ values were significantly reduced in all treatments at the end of the storage $\left(10^{\text {th }}\right.$ day). At $5{ }^{\circ} \mathrm{C}$, the $\mathrm{P} 1, \mathrm{P} 2, \mathrm{P} 3$, and $\mathrm{C}$ had significant in-between differences while $\mathrm{C}$ and $\mathrm{P} 3$ samples exhibited the highest, chroma reduction which was $21 \%$.

The initial hue angle $\left(\mathrm{h}^{*}\right)$ was $117.5 \pm 1.8$ and presented not significant variations throughout the storage. The $10^{\text {th }}$ day of the experiment, at $0{ }^{\circ} \mathrm{C}$, the $\mathrm{P} 1$ and $\mathrm{P} 2$ were significant different from $\mathrm{P} 3$ and control samples. At $5{ }^{\circ} \mathrm{C}, \mathrm{P} 1$, $\mathrm{P} 2$ and $\mathrm{C}$ did not have any in-between significant differences although they were significant different from the P3. In conclusion, low $\mathrm{L}^{*}$ or high $\mathrm{h}^{*}$ angle values at the end of the storage, indicated retention of the initial green colour which may be due to limited dehydration and/or limited chlorophyll degradation which is responsible for the green colour. Retention of the green colour due to limited chlorophyll degradation in fruits and vegetables can also initiated from the elevated $\mathrm{CO}_{2}$ and/or low $\mathrm{O}_{2}$ in-package concentrations according to Weichmann (1986). In all cases, the small $\mathrm{L}^{*}$ reduction $(<14 \%)$, and $\mathrm{h}^{*}$ retention, throughout the MAP storage indicated retention of the initial green colour of the fresh-cut produce. 
Table 2. ANOVA of the factors and their interactions affecting the $\mathrm{L}^{*}, \mathrm{C}^{*}$ and $\mathrm{h}^{*}$ colour parameters of the packaged fresh-cut peppers stored at 0 and $5{ }^{\circ} \mathrm{C}$

\begin{tabular}{|c|c|c|c|c|c|}
\hline & & $\mathrm{df}$ & $\mathrm{L}^{*}$ & $\mathrm{C}^{*}$ & $\mathrm{~h}^{*}$ \\
\hline \multirow{3}{*}{ 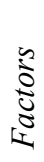 } & A: treatment & 3 & $1.95^{*}$ & $2.43 *$ & $1.64 *$ \\
\hline & B: storage temperature & 1 & $0.14^{\mathrm{NS}}$ & $0.82 *$ & $2.01 *$ \\
\hline & C: storage time & 3 & $3.10^{\mathrm{NS}}$ & $5.18 *$ & $2.70^{\mathrm{NS}}$ \\
\hline \multirow{4}{*}{$\begin{array}{l}0 \\
0 \\
0 \\
0 \\
0 \\
0 \\
\Xi \\
\Sigma\end{array}$} & $\mathrm{A} \times \mathrm{B}$ & 3 & $0.15^{\mathrm{NS}}$ & $0.48^{*}$ & $1.38^{*}$ \\
\hline & $\mathrm{A} \times \mathrm{C}$ & 9 & $1.12 *$ & $2.08 *$ & $0.46^{\mathrm{NS}}$ \\
\hline & $\mathrm{B} \times \mathrm{C}$ & 3 & $2.10^{\mathrm{NS}}$ & $1.15^{\mathrm{NS}}$ & $1.48^{*}$ \\
\hline & $\mathrm{A} \times \mathrm{B} \times \mathrm{C}$ & 9 & $1.56^{\mathrm{NS}}$. & $0.93^{\mathrm{NS}}$. & $1.20 *$ \\
\hline
\end{tabular}

$\mathrm{NS}=$ not significant; $*=$ significant at $\mathrm{p} \leq 0.05$; $\mathrm{SST}=$ total sum of squares; $\mathrm{df}=$ =egree of freedom.

Table 3. Effect of storage temperature, treatment and storage time on the $\mathrm{L}^{*}, \mathrm{C}^{*}$ and $\mathrm{h}^{*}$ colour parameters of the packaged fresh-cut peppers stored at 0 and $5{ }^{\circ} \mathrm{C}$

\begin{tabular}{|c|c|c|c|c|c|c|c|c|}
\hline \multirow{2}{*}{$\begin{array}{c}\text { Colour } \\
\text { parameter }\end{array}$} & \multicolumn{2}{|c|}{$0^{\text {th }}$ day } & \multicolumn{2}{|c|}{$3^{\text {rd }}$ day } & \multicolumn{2}{|c|}{$6^{\text {th }}$ day } & \multicolumn{2}{|c|}{$10^{\text {th }}$ day } \\
\hline & $0{ }^{\circ} \mathrm{C}$ & $5^{\circ} \mathrm{C}$ & $0{ }^{\circ} \mathrm{C}$ & $5^{\circ} \mathrm{C}$ & $0{ }^{\circ} \mathrm{C}$ & $5^{\circ} \mathrm{C}$ & $0{ }^{\circ} \mathrm{C}$ & $5^{\circ} \mathrm{C}$ \\
\hline \multicolumn{9}{|c|}{$L^{*}$} \\
\hline P1 & $32.5 \pm 3.4$ & $32.5 \pm 3.4$ & $29.1 \pm 2.5$ & $32.4 \pm 2.8$ & $28.9 \pm 2.9$ & $30.7 \pm 2.7$ & $29.2 \pm 1.9$ & $30.4 \pm 2.2$ \\
\hline P2 & $32.5 \pm 3.4$ & $32.5 \pm 3.4$ & $33.6 \pm 2.6$ & $31.3 \pm 2.1$ & $29.8 \pm 3.3$ & $30.4 \pm 3.0$ & $27.9 \pm 2.5$ & $32.8 \pm 2.5$ \\
\hline P3 & $32.5 \pm 3.4$ & $32.5 \pm 3.4$ & $33.2 \pm 2.7$ & $32.6 \pm 2.8$ & $31.5 \pm 4.9$ & $33.9 \pm 4.0$ & $32.9 \pm 4.0$ & $31.3 \pm 4.5$ \\
\hline Control & $32.5 \pm 3.4$ & $32.5 \pm 3.4$ & $30.9 \pm 3.9$ & $31.5 \pm 4.4$ & $31.5 \pm 4.7$ & $31.4 \pm 4.9$ & $30.8 \pm 4.8$ & $32.1 \pm 4.5$ \\
\hline \multicolumn{9}{|c|}{$C^{*}$} \\
\hline P1 & $25.8 \pm 2.6$ & $25.8 \pm 2.6$ & $21.5 \pm 2.4$ & $23.7 \pm 2.6$ & $23.2 \pm 2.5$ & $22.7 \pm 2.2$ & $23.9 \pm 2.1$ & $23.2 \pm 2.6$ \\
\hline P2 & $25.8 \pm 2.6$ & $25.8 \pm 2.6$ & $25.5 \pm 2.6$ & $24.1 \pm 2.6$ & $24.1 \pm 2.6$ & $23.9 \pm 2.2$ & $23.6 \pm 2.4$ & $25.9 \pm 2.2$ \\
\hline P3 & $25.8 \pm 2.6$ & $25.8 \pm 2.6$ & $24.4 \pm 2.7$ & $21.9 \pm 2.5$ & $22.9 \pm 2.9$ & $21.4 \pm 2.1$ & $22.9 \pm 3.9$ & $20.3 \pm 2.8$ \\
\hline Control & $25.8 \pm 2.6$ & $25.8 \pm 2.6$ & $22.4 \pm 3.3$ & $20.8 \pm 256$ & $22.4 \pm 2.5$ & $20.5 \pm 3.2$ & $21.4 \pm 2.6$ & $20.4 \pm 3.5$ \\
\hline \multicolumn{9}{|c|}{$h^{*}$} \\
\hline P1 & $117.5 \pm 1.8$ & $117.5 \pm 1.8$ & $118.9 \pm 2.1$ & $116.5 \pm 2.2$ & $118.6 \pm 2.1$ & $118.2 \pm 1.9$ & $117.3 \pm 3.0$ & $117.9 \pm 2.0$ \\
\hline $\mathrm{P} 2$ & $117.5 \pm 1.8$ & $117.5 \pm 1.8$ & $118.1 \pm 2.0$ & $116.0 \pm 2.0$ & $117.7 \pm 2.2$ & $117.4 \pm 2.4$ & $117.5 \pm 2.4$ & $117.3 \pm 1.9$ \\
\hline P3 & $117.5 \pm 1.8$ & $117.5 \pm 1.8$ & $118.1 \pm 2.0$ & $116.0 \pm 2.6$ & $117.4 \pm 1.8$ & $117.4 \pm 2.6$ & $118.4 \pm 2.0$ & $115.8 \pm 3.0$ \\
\hline Control & $117.5 \pm 1.8$ & $117.5 \pm 1.8$ & $118.0 \pm 1.8$ & $117.1 \pm 2.7$ & $118.1 \pm 2.0$ & $116.7 \pm 3.2$ & $118.5 \pm 1.7$ & $117.3 \pm 3.2$ \\
\hline
\end{tabular}

$0{ }^{\circ} \mathrm{C}: \overline{\text { LSDL }^{*}=0.98 ; \mathrm{LSDC}^{*}=0.47 ; \mathrm{LSDh}^{*}=0.36 ; 5^{\circ} \mathrm{C}: \mathrm{LSDL}^{*}=0.99 ; \mathrm{LSDC}^{*}=0.64 ; \mathrm{LSDh}^{*}=0.30 ; \text { means } \pm \text { std }}$.

\subsection{Ascorbic Acid}

The initial ascorbic acid $\left(128.5 \pm 2.0 \mathrm{mg} 100 \mathrm{~g}^{-1}\right.$ of initial mass) retained in all treatments throughout the storage at $0{ }^{\circ} \mathrm{C}$ (cf. Table 4). However, at $5{ }^{\circ} \mathrm{C}$ a significant increase in the ascorbic acid (P1: $32 \%$, P2: $25 \%$, P3: $29 \%$ and C: $52 \%$ ) was observed at the end of the storage, highlighting the temperature dependence of the ascorbic acid. These results agree with Senesi et al. (2000) and Gonzaléz-Aguilar et al. (2004) experiments on shelf-life of fresh-cut peppers under passive MAP. The combined effect of low storage temperatures $\left(0\right.$ and $\left.5{ }^{\circ} \mathrm{C}\right)$ and MAP was beneficial in retaining the initial ascorbic acid, although Klein (1987) referred that minimal processing result in loss of the ascorbic acid in fresh-cut than in intact produce as the oxidative process is accelerated. In contradictory conclusions (retention or increase of the ascorbic acid) were driven also Barth, Kerbel, Perry \& Schmidt (1993), Paradis et al. (1996) for broccoli, and Howard \& Hernandez-Brenes (1998) for jalapeno pepper storage. 
Table 4. Effect of storage temperature, treatment and storage time on the mean ascorbic acid $\left(\mathrm{mg} 100 \mathrm{~g}^{-1}\right)$ of packaged fresh-cut peppers stored at 0 and $5{ }^{\circ} \mathrm{C}$

\begin{tabular}{cccccc}
\hline $\begin{array}{c}\text { Storage } \\
\text { temperature }\end{array}$ & & \multicolumn{4}{c}{ Ascorbic acid $(\mathrm{mg} / 100 \mathrm{~g})$} \\
& & $\mathrm{P} 1$ & $\mathrm{P} 2$ & $\mathrm{P} 3$ & Control \\
\hline & $0^{\text {th }}$ day & $128.5 \pm 2.0 \mathrm{aA}$ & $128.5 \pm 2.0 \mathrm{aA}$ & $128.5 \pm 2.0 \mathrm{aA}$ & $128.5 \pm 2.0 \mathrm{aA}$ \\
${ }^{\circ} \mathrm{C}$ & $10^{\text {th }}$ day & $124.0 \pm 2.8 \mathrm{Aa}$ & $119.5 \pm 1.2 \mathrm{aA}$ & $127.1 \pm 2.4 \mathrm{aA}$ & $126.2 \pm 1.5 \mathrm{aA}$ \\
$5{ }^{\circ} \mathrm{C}$ & $10^{\text {th }}$ day & $170.2 \pm 1.4 \mathrm{aB}$ & $160.2 \pm 2.1 \mathrm{aB}$ & $166.3 \pm 3.2 \mathrm{aB}$ & $195.2 \pm 4.1 \mathrm{bB}$ \\
\hline
\end{tabular}

Values in the same column followed by different uppercase letters show significant differences between temperatures, $\mathrm{p} \leq 0.05$; Values in the same row followed by different lowercase letters show significant differences among treatments, $\mathrm{p} \leq 0.05$; Means \pm std.

\subsection{Overall Visual Quality}

The appearance of the fresh-cut produce was evaluated visually. The ANOVA (cf. Table 5) showed that the interaction of storage temperature with storage time affected significantly the visual quality of the fresh-cut produce. The previous inference is showed in Figure 5 , where at $5{ }^{\circ} \mathrm{C}$ was found higher visual degradation than at $0{ }^{\circ} \mathrm{C}$ which agrees with Lopéz-Galvez, El-Bassuoni, Nie, \& Cantwell (1997) who studied the visual degradation of red and green fresh-cut peppers under CA storage. Although Kang \& Lee (1997) referred that storage of fresh-cut pepper at $5{ }^{\circ} \mathrm{C}$ can initiate chilling injuries, this was not confirmed in this study where chilling injuries did not found in any of the tested cases. The combined effect of minimal processing and MAP, according to Forney \& Lipton (1990) and Gorny (2001), permit the use of low storage temperatures $\left(-5^{\circ} \mathrm{C}\right.$ $0{ }^{\circ} \mathrm{C}$ ), with no danger of chilling injury occurrence. The low $\mathrm{O}_{2}$ conditions at $0{ }^{\circ} \mathrm{C}$ and $5{ }^{\circ} \mathrm{C}$ did not produce off-flavours in the fresh-cut produce according to the panelists, which agree with González-Aguilar et al. (2004) who reported that traces of ethanol and acetaldehyde, produced during storage of fresh-cut green pepper at $8{ }^{\circ} \mathrm{C}$ were not sufficient to affect the sensory susceptibility of the end-product.

Table 5. Analysis of variance of storage temperature, treatment and storage time and their interactions as these affect the visual quality of the packaged fresh-cut peppers stored at 0 and $5{ }^{\circ} \mathrm{C}$

\begin{tabular}{|c|c|c|c|}
\hline & & $\mathrm{df}$ & Visual Quality \\
\hline \multirow{3}{*}{ 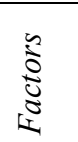 } & A: Storage temperature & 1 & $10.57 \% *$ \\
\hline & B: Treatment & 3 & $39.74 \% *$ \\
\hline & C: Storage time & 2 & $11.24 \% *$ \\
\hline \multirow{4}{*}{ 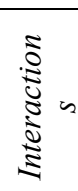 } & $\mathrm{A} \times \mathrm{B}$ & 3 & $0.12 \%^{\mathrm{NS}}$ \\
\hline & $\mathrm{A} \times \mathrm{C}$ & 2 & $5.20 \% *$ \\
\hline & $\mathrm{B} \times \mathrm{C}$ & 6 & $3.11 \%^{\mathrm{NS}}$ \\
\hline & $\mathrm{A} \times \mathrm{B} \times \mathrm{C}$ & 6 & $1.53 \%^{\mathrm{NS}}$ \\
\hline
\end{tabular}

$\mathrm{NS}=$ not significant; $*=$ significant to $\mathrm{p} \leq 0.05$; $\mathrm{SST}=$ total sum of squares; $\mathrm{df}=$ =egree of freedom.
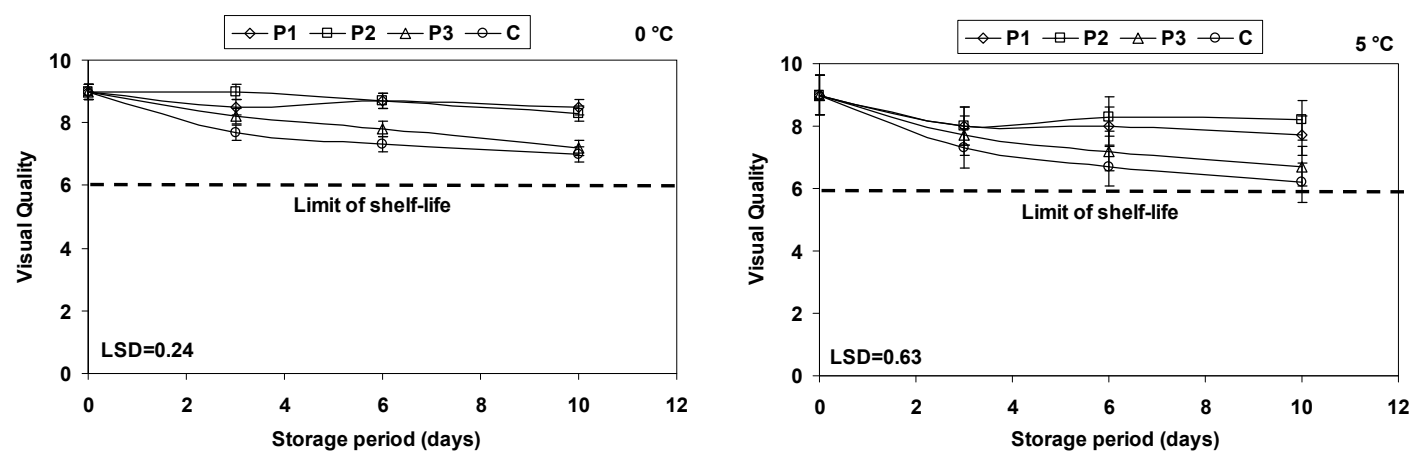

Figure 5. Visual quality of packaged fresh-cut peppers stored at 0 and $5{ }^{\circ} \mathrm{C} . \mathrm{P} 1, \mathrm{P} 2$ and $\mathrm{P} 3$ are $\mathrm{O}_{2}: \mathrm{CO}_{2}$ mixtures respectively 5\%:10\%,5\%:15\%,21\%:0.03\%. C denotes control samples. Data points are the means of 108 replicates \pm LSD 


\section{Conclusions}

The RR of the unpackaged fresh-cut produce was $24 \%$ higher than of the whole produce at $5{ }^{\circ} \mathrm{C}$. The analysis showed that temperature control in minimally processed products is crucial for the related metabolic activity control. The in-package formed atmospheres found to be temperature, storage time and treatment dependent. At $5{ }^{\circ} \mathrm{C}$ the $\mathrm{O}_{2}$ reduced significantly until the $5^{\text {th }}$ day, although no tissue injuries or off flavours were detected at the end-product. No significant differences were found in the $\mathrm{O}_{2}$ levels at $0{ }^{\circ} \mathrm{C}$ and $5{ }^{\circ} \mathrm{C}$ for the tested initial $\mathrm{O}_{2}$ and $\mathrm{CO}_{2}$ concentrations (P1 and P2). As the $\mathrm{CO}_{2}$ level concerns, significant differences detected among the P1, P2 and $\mathrm{P} 3$ treatments. Mass loss was significantly affected by the storage temperature, storage time and treatment in $\mathrm{P} 1, \mathrm{P} 2$ and P3 treatments. Only treatment and storage time affected significantly firmness. At $0{ }^{\circ} \mathrm{C}$ the increase of the firmness at the end of the storage was significant in $\mathrm{P} 1$ and $\mathrm{P} 2$ treatments whereas at $5{ }^{\circ} \mathrm{C}$ the increase was significant only in P1 treatment. A mathematical correlation was developed relating mass loss, firmness and the tested treatments with satisfactory accuracy $\left(\mathrm{R}_{\mathrm{adj}}^{2}=0.633\right)$. In all treatments the initial green colour was retained throughout the storage based on the final $h^{*}$ value which was not significantly different from the initial $h^{*}$ value. A significant increase of the ascorbic acid was observed at the end of the storage at $5{ }^{\circ} \mathrm{C}$. The visual quality significantly affected from the storage temperature and storage time. Significant visual degradation observed at $5{ }^{\circ} \mathrm{C}$ although the scored values were above the acceptable limit. From the previous findings, can be concluded that fresh-cut bell peppers (cv Twingo F1) stored at $0{ }^{\circ} \mathrm{C}$ under the tested active MAP conditions can maintain a qualitative shelf-life up to 10 days.

\section{References}

Abe, K., Yoshimura, K., Zhou, Y. F., \& Iwata, T. (1991). Studies on physiological and chemical changes of partially processed sweet peppers fruit, II. Change of chemical compounds in cut surface of sweet pepper in relation to difference of storability by shredding direction. J. of Jpn Soc. of Cold Preservation of Food, 17, 146-151. http://dx.doi.org/10.5891/jafps1987.17.146

Ahvenainen, R. (2000). Minimal processing of fresh produce. In: Minimally Processed Fruits and Vegetables, (M.S., Alzamora, M.S., Tapia, López-Malo, Aurelio, eds.). An Aspen Publication, p. 277-290.

AOAC. (1990). Official methods of analysis of the Association of Official Analytical Chemists (15 $5^{\text {th }}$ ed.) Association of Official Analytical Chemists.

Artés, F., Gómez, P., Aguayo, E., Escalona, V., \& Artés-Hernández, F. (2009). Sustainable sanitation techniques for keeping quality and safety of fresh-cut plant commodities. Postharvest Biol. Tec., 51, 287-296. http://dx.doi.org/10.1016/j.postharvbio.2008.10.003

Barth, M. M., Kerbel, E. L., Perry, A. K., \& Schmidt, S. J. (1993). Modified atmosphere packaging affects ascorbic acid, enzyme activity and market quality of broccoli. J. Food Sci., 58(1), 140-143. http://dx.doi.org/10.1111/j.1365-2621.1993.tb03230.x

Beaulieu, J. C. (2011). Factors affecting sensory quality of fresh-cut produce. In: Advances in Fresh-Cut Fruits and Vegetables Processing, (O., Martín-Belloso, R., Soliva-Fortuny, eds.). CRC Press, Taylor and Francis Group, NY.

Cantwell, M. I., \& Suslow, T. V. (2002). Postharvest handling systems: Fresh-cut fruits and vegetables In: Postharvest Technology of Horticultural Crops. University of California, Publication 331, pp. 445-463.

Conésa, A., Artés-Hernández, F., Geysen, S., Bart, N., \& Artés, F. (2007). High oxygen combined with high carbon dioxide improves microbial and sensory quality of fresh-cut peppers. Postharvest Biol. Tec., 43(2), 230-237. http://dx.doi.org/10.1016/j.postharvbio.2006.08.016

Forney, C. F., \& Lipton, W. Z. (1990). Influence of controlled atmosphere and packaging on chilling sensitivity. In: Chilling injury of horticultural crops, (J., Wang ed.). CRC press, Florida, USA. pp. 227-268

Gacula, M. C., \& Singh, J. (1984). Statistical Methods in Food and Consumer Research. Academic Press, Inc., New York, USA.

Gil, M. I., Allende, A., \& Selma M. V. (2011). Treatments to ensure safety of fresh -cut fruits and vegetables. In: Advances in Fresh-Cut Fruits and Vegetables Processing, (O., Martín-Belloso, R., Soliva-Fortuny, eds.). CRC Press, Taylor and Francis Group, NY, USA.

Gil, M. I., Selma, M. V., López-Gálvez, F., \& Allende, A. (2009). Fresh-cut product sanitation and wash water disinfection: Problems and solutions (Review). Int. J. Food Microbiol., 134, 37-45. http://dx.doi.org/10.1016/j.ijfoodmicro.2009.05.021

Gonzaléz-Aguilar, G. A, Ayala-Zavala J. F., Ruiz-Cruz S., Acedo-Félix E., \& Diaz-Cinco M. E. (2004). Effect of 
temperature and modified atmosphere packaging on overall quality of fresh-cut bell peppers. Lebensm Wiss Technol, 37(8), 817-826. http://dx.doi.org/10.1016/j.lwt.2004.03.007

Gorny, R. J. (2001). A summary of C.A and M.A requirements and recommendations for fresh-cut (minimally processed) fruits and vegetables. In: Optimal controlled atmospheres for Horticultural perishables, (University of Davis, ed.) Postharvest Horticultural series, No 22a , pp. 95-103.

Howard, L. R., \& Hernandez-Brenes, C. (1998). Antioxidant content and market quality of jalapeno pepper rings as affected by minimal processing and modified atmosphere packaging. J. Food Quality, 21(4), 317-327. http://dx.doi.org/10.1111/j.1745-4557.1998.tb00525.x

Huxsoll, C. C., \& Bolin, H. R. (1989). Processing and distribution alternatives for minimally processed fruits and vegetables. Food Technol.-Chicago, 43, 124-128.

Kang, J. S., \& Lee, D. S. (1997). Susceptibility of minimally processed green pepper and cucumber to chilling injury by apparent respiration rate. Int. J. Food Sci. Tech., 32(5), 421-426. http://dx.doi.org/10.1046/j.1365-2621.1997.00129.x

Klein, B. P. (1987). Nutritional consequences of minimally processing of fruits and vegetables. J. Food Quality, 10(3), 179-193. http://dx.doi.org/10.1111/j.1745-4557.1987.tb00857.x

Lopéz-Galvez, G., El-Bassuoni, R., Nie, X., \& Cantwell, N. (1997). Quality of red and green fresh-cut peppers stored in C.A. In: Fresh-cut fruits and vegetables and MAP, (J. Gorny ed.). University of California Davis, USA (5), 152-157.

Manolopoulou, H., Xanthopoulos, G., Douros, N., \& Lambrinos, Gr. (2010). Modified atmosphere packaging storage of green bell peppers: quality criteria. Biosystems Eng., 106, 535-543. http://dx.doi.org/10.1016/j.biosystemseng.2010.06.003

Mcguire, R. G. (1992). Reporting of objective colour measurements. HortScience, 27, 1254-1255.

Mitropoulos, D., Lamprinos, Gr., \& Manolopoulou, H. (2000). A portable setup for fruit respiration measurement. In: Improving postharvest technologies of fruits, vegetables and ornamentals, (Gil, Artés and Conesa, eds.). International Institute of Refrigeration, 2, 926-931.

Nunes, M. C. N., \& Emond, J. P. (2003). Storage temperature, In: Bartz, J.A. and Brecht J.K. (eds), Postharvest Physiology-Pathology of Vegetables, Marcel-Dekker Inc. NY, USA, pp. 209-228.

Ohlsson, T. (1994). Minimal processing-preservation methods of the future. An overview. Trends Food Sci. Tech., 5(11), 341-344. http://dx.doi.org/10.1016/0924-2244(94)90210-0

Oms-Oliu, G., \& Soliva-Fortuny, R. (2011). Future trends in fresh-cut fruit and vegetable processing. In: Martín-Belloso, O., Soliva-Fortuny, R. (eds.). Advances in Fresh-Cut Fruits and Vegetables Processing. CRC Press, Taylor and Francis Group, NY, USA.

Paradis, C., Castaigne, F., Desrosiers, T., Fortin, J., Rodrigue, N., \& Willemot, C. (1996). Sensory nutrient and chlorophyll changes in broccoli florets during controlled atmosphere storage. J. Food Quality, 19(4), 303-316. http://dx.doi.org/10.1111/j.1745-4557.1996.tb00425.x

Raffo, A., Baimonte, I., \& Paoletti, F. (2008). Changes in antioxidants and taste related compounds content during cold storage of fresh-cut red sweet peppers. Eur.Food Res. Tech., 226(5), 1167-1174. http://dx.doi.org/10.1007/s00217-007-0646-4

Senesi, E., Prinzivalli, C., Sala, M., \& Gennari, M. (2000). Physicochemical and microbiological changes in fresh-cut green bell peppers as affected by packaging and storage. Ital. J. Food Sci., 12(1), 55-64.

Smith, A. C., Waldron, K. W., Maness, N., \& Perkins-Veazie, P. (2003). Vegetable texture: Measurement and structural implications. In: Postharvest physiology and pathology of vegetables, (J. A., Bartz, and J. K., Brecht, eds.), $2^{\text {nd }}$ ed. Marcel Dekker, Inc., NY, USA, pp. 297-331)

Varoquaux, P., \& Mazollier, J. (2002). Overview of the European fresh-cut produce industry. In: Olusola L. (ed.). Fresh-cut Fruits and Vegetables. CRC Press, NY, USA. pp. 21-43.

Weichmann, J. (1986). The effect of controlled atmosphere storage on the sensory and nutritional quality of fruits and vegetables. In: Horticultural Reviews, (Janick, ed.), 8, 102-103.

Zhou, Y. F., Abe, K., \& Iwata, T. (1992). Effect of shredding modes on the deterioration of the quality of partially processed pepper fruits. Nippon Shokuhin Kogyo Gakkaishi, 39, 161-166. http://dx.doi.org/10.3136/nskkk1962.39.161 